\title{
Peningkatan Mutu Pelayanan RSI Unisma Malang Melalui Reformasi Manajemen Laundry dan Linen
}

\section{Service Quality Improvement at Unisma Malang through Laundry and Linen Management Reformation}

\author{
Jamilatus Syamsiah A, Tri Wahyu S, Muhammad Mansur \\ ${ }^{1}$ Program Studi Magister Manajemen Rumah Sakit Fakultas Kedokteran Universitas Brawijaya Malang \\ ${ }^{2}$ Rumah Sakit Islam Unisma Malang \\ ${ }^{3}$ Program Studi Magister Manajemen Rumah Sakit Fakultas Kedokteran Universitas Brawijaya Malang
}

\begin{abstract}
ABSTRAK
Pelayanan linen yang tidak memenuhi standar seperti jumlah linen kurang, kebersihan linen kurang, ketidaktepatan waktu dalam pelayanan linen akan mempengaruhi mutu pelayanan rumah sakit. Disamping itu berdampak juga kepada pembiayaan kebutuhan linen yang tidak efisien dan menurunnya kepuasan pasien terhadap pelayanan linen. Penelitian ini merupakan studi deskriptif yang bertujuan untuk mencari akar masalah dan alternatif solusi tentang ketidaktepatan waktu penyediaan linen rawat inap di RSI Unisma Malang. Penelitian ini menggunakan responden sejumlah 10 orang yang terdiri dari kepala ruang dan petugas linen rawat inap. Penentuan akar masalah menggunakan diagram fishbone, identifikasi alternatif solusi masalah menggunakan media Focus Group Discussion (FGD) dengan pemilihan solusi melalui teori tapisan Mc Namara. Dari hasil penelitian yang terkait dengan ketidaktepatan waktu penyediaan linen adalah belum adanya struktur organisasi, Standar Prosedur Operasional (SPO) waktu pelayanan linen, kualifikasi Sumber Daya Manusia (SDM), pelatihan manajemen linen, dan kebijakan yang mengatur standar waktu pelayanan linen. Alternatif solusi yang dipilih berdasarkan teori tapisan Mc Namara adalah memperbaiki manajemen linen.
\end{abstract}

Kata Kunci: Ketidaktepatan waktu, linen, ruang rawat inap

\section{ABSTRACT}

Understandard linen services such as not enough linen, non-hygiene linen, and time inaccuracy in linen service will affect the quality of hospital services. Besides, it also affects inefficient financing on linen demand and decreases patient satisfaction on linen service. This research is a descriptive study aiming to find the root of problem and alternative solutions regarding time inaccuracies of linen provision in inpatient unit Unisma Islamic Hospital Malang. This study uses 10 respondents including room head and linen attendants in inpatient unit. Determining the root of the problem was using fishbone diagrams, and the identification of alternative solutions was using Focus Group Discussion (FGD) media with solution selection through Mc Namara theory. From the research results, time inaccuracy on linen provision is because of absence of organizational structure, Standard Operating Procedure (SOP) on linen service time, Human Resources (HR) qualification, linen management training, and policies governing the standard time of linen service. Alternative solution chosen based on Mc Namara theory is to improve the linen management.

Keywords: Inpatient ward, linen, time inaccuracy

Jurnal Kedokteran Brawijaya, Vol. 28, Suplemen No. 2, 2015; Korespondensi: Jamilatus Syamsiah Anwar. Program Studi Magister Manajemen Rumah Sakit Fakultas Kedokteran Universitas Brawijaya Malang, Jl. Veteran Malang 65145 Tel. (0341) 569117 Email: nu_syam@yahoo.com 


\section{PENDAHULUAN}

Rumah Sakit Islam Unisma adalah rumah sakit umum swasta dengan kelas C. Kinerjanya dapat dilihat dari BOR (Bed Occupation Rate) tahun 2012: 39,1\%, tahun 2013: $53,7 \%$ (standar nasional yaitu 60-85\%). Kondisi ini menggambarkan pemanfaatan tempat tidur pada pelayanan rawat inap RSI Unisma Malang mengalami peningkatan. Efisiensi penggunaan tempat tidur (TOI/Turn Over Interval) 2 tahun terakhir mendekati standar yang ditentukan, yaitu tahun 2012: 4,7 hari, tahun 2013: 3,4 hari ( standar nasional yaitu 1-3 hari). ALOS (Average Lenght of Stay) tahun 2012: 2,9 hari, tahun 2013: 3,5 hari (standar nasional yaitu 6-9 hari). Kondisi ini menggambarkan selisih waktu pemakaian tempat tidur di RSI Unisma kurang dari standar.

Capaian kinerja berdasarkan perbandingan antara SPM Rumah Sakit Kemenkes nomor 129/MENKES/SK/II/2012 dengan indikator RSI Unisma Malang ditemukan beberapa permasalahan yang saat ini dihadapi oleh RSI Unisma Malang. Dari 17 jenis layanan yang terdiri dari 131 indikator SPM RSI Unisma Malang, terdapat 13 indikator pelayanan $(9,9 \%)$ yang belum terukur dan 19 indikator pelayanan $(14,5 \%)$ yang belum tercapai. Sehingga indikator pelayanan RSI Unisma Malang yang tercapai adalah $75,6 \%$.

Indikator yang tidak tercapai, salah satunya adalah di pelayanan laundry, yaitu ketepatan waktu penyediaan linen untuk ruang rawat inap dan ruang pelayanan sebesar $75 \%$ (standar $100 \%$ ). Hal ini berdampak pada misi rumah sakit tidak terpenuhi, yaitu memberikan pelayanan prima berdasarkan etika, disiplin profesi yang dijiwai nilai keislaman.Pelayanan linen yang kurang memuaskan seperti linen tidak memenuhi standar kebersihan, jumlah linen kurang sehingga mempengaruhi ketersediaan linen di rawat inap, linen hilang, linen tidak layak pakai lagi atau rusak namun tetap digunakan akan mempengaruhi mutu pelayanan rumah sakit, efisiensi biaya dan kepuasan pasien (1).

Perencanaan kebutuhan linen yang tepat menjadi salah satu faktor utama kelancaran operasional linen (2). Kebutuhan linen di setiap ruangan sangat bervariasi, baik jenis linen, jumlah linen, dan kondisi ruangan (1). Perencanaan linen juga bertujuan untuk mencegah terjadinya infeksi silang (infeksi nosokomial bagi pasien dan petugas rumah sakit dengan mengelola dan mengendalikan bahan-bahan linen), menjaga citra rumah sakit dengan menciptakan ketersediaan bahan linen sesuai dengan visi dan misi serta filosofi rumah sakit, mengelola sumber daya rumah sakit untuk menyediakan linen bagi kebutuhan dan harapan pelanggan rumah sakit (3).

Ada kecenderungan terjadi peningkatan angka kejadian infeksi nosokomial tiap semester di RSI Unisma Malang. Hal ini ditunjukkan dengan adanya data kejadian infeksi nosokomial di RSI Unisma Malang tahun 2013 sebanyak $3,7 \%, 3,75 \%$ pada trimester 1 tahun 2014, dan 11,57\% pada trimester 2 tahun 2014. Standar Kemenkes tahun 2012 untuk infeksi nosokomial adalah kurang dari 9\%. Kecenderungan peningkatan kejadian infeksi nosokomial harus diwaspadai karena akan menimbulkan dampak negatif bagi pelayanan rumah sakit.

Penelitian yang dilakukan pada 69 sampel linen pada salah satu rumah sakit di India ditemukan bakteri Pseudomanas $20 \%$ dan Aerobic spores $20 \%$ pada selimut pasien,
Pseudomanas 16,7\% dan Aerobic spores 16,7\% pada sprei, Aerobic spores $20 \%$ pada sarung bantal pasien, Klebsiella $20 \%$ pada baju pasien, Aerobic spores $20 \%$ pada surgeon gown, Pseudomanas $40 \%$ pada trolli (4). Linen yang kotor akan mempengaruhi kondisi psikologis dan kepuasan pasien. Pasien selalu menghendaki agar linen diganti setiap harinya (4). Penelitian di RS India menunjukkan bahwa pelayanan linen dan laundry yang efisien dan efektif relevan dengan kualifikasi, pengalaman, dan pelatihan dari SDM linen dan laundry (5). Pemeliharaan sarana fisik, prasarana, peralatan serta prosedur yang baik dapat menimbulkan efisiensi kerja, meminimalkan pencemaran lingkungan, dan melindungi kualitas linen (4).

\section{METODE}

Penelitian dilakukan secara deskriptif analitik untuk mengidentifikasi faktor-faktor penyebab ketidaktepatan waktu penyediaan linen di ruang rawat inap. Metode yang digunakan adalah studi dokumen, laporan kinerja dan pelayanan rumah sakit, observasi unit pelayanan, wawancara dan kuesioner. Wawancara dilakukan pada Manajer Umum, Kepala dan staf Unit Rumah Tangga. Kuesioner dibagikan kepada Kepala Ruang dan pekarya rawat inap.

Penelitian dilakukan di instalasi rawat inap RSI Unisma Malang pada bulan Oktober 2014 dengan menggunakan teknik purposive sampling dengan responden sejumlah 10 orang yang terdiri dari 5 kepala ruang rawat inap dan 5 petugas linen rawat inap. Pertanyaan pada kuesioner diambil dari penelitian sebelumnya dengan judul"Quality Control in Linen and Laundry Service at A Tertiary Care Teaching Hospital in India" oleh Dara S, et al (4). Pertanyaan pada kuesioner meliputi kepuasan staf ruang rawat inap tentang pelayanan linen dan laundry yang merupakan pertanyaan tertutup. Opsi jawaban terdiri dari jawaban "ya" dan "tidak". Terdapat pertanyaan terbuka mengenai informasi, saran, dan masukan terhadap ketidaktepatan waktu penyediaan linen di ruang rawat inap. Penentuan akar masalah menggunakan metode fishbone.

Setelah prioritas akar masalah ditentukan maka langkah selanjutnya adalah mencari alternatif solusi. FGD dilaksanakan pada tanggal 21 Oktober 2014 yang dihadiri Manajer Umum, Kepala Rumah Tangga, IPCN (Infection Prevention and Control Nurse), petugas laundry dan linen. Pemilihan alternatif solusi adalah dengan teori tapisan Mc Namara, yaitu menentukan 3 kriteria yang dinilai dari setiap alternatif yaitu kontribusi, kemurahan, dan kelayakan. Tiap kriteria diberikan skor nilai antara 1-5. Total skor tertinggi adalah solusi permasalahan yang dipilih (6).

\section{HASIL}

Penyebab masalah ketidaktepatan waktu penyediaan linen mengacu pada perspektif manajemen $4 \mathrm{M}$ dan $1 \mathrm{E}$ sesuai dengan penelitian yang telah dilakukan oleh Dara $\mathrm{S}$ et al, yaitu Man, Material, Machine, Management, dan Environment (4). Informasi mengenai perspektif 4M dan 1 E didapatkan dari hasil kuesioner dan brainstorming yang dilakukan peneliti dengan Manajer Umum, Kepala Rumah Tangga, IPCN (Infection Prevention and Control Nurse), dan petugas laundry\& linen.

Tabel. 1 menjelaskan bahwa petugas laundry dan linen yang terdiri dari 4 petugas, 3 diantaranya berpendidikan 
SD yang menunjukkan belum memenuhi kualifikasi petugas laundry dan linen. Petugas laundry dan linen belum mendapatkan pelatihan manajemen linen sehingga petugas kurang paham mengenai manajemen linen. Petugas laundry \& linen tidak dapat bekerjasama dengan baik dinyatakan oleh $20 \%$ responden. Salah satu contohnya adalah ketika petugas laundry \& linen diberi masukan mengenai hasil linen yang masih ada noda darah dan minyak, respon petugas tidak cukup baik terhadap masukan yang diberikan adalah belum ada struktur organisasi laundry sehingga staf tidak mempunyai job description (tugas dan tanggungjawab) dan job specification (kualifikasi yang harus dimiliki petugas).

Pada ruang rawat inap kelas 1 ditemukan bahwa jumlah linen belum memenuhi perhitungan linen Jumlah standar kebutuhan linen rawat inap kelas 1 adalah 51 buah. Hasil ini didapatkan dari rumus kebutuhan linen berdasarkan Pedoman Manajemen Linen Rumah Sakit, yaitu 3 PAR dikali jumlah tempat tidur pada rawat inap kelas 1 (21 buah) dikali rata-rata bed occupancy ratio (BOR) dalam 1 tahun $(0,81 \%)$. Ketersediaan linen di ruang rawat inap kelas 1 pada saat penelitian adalah 42 buah. Jumlah linen yang tidak mencukupi dan kurang optimalnya mesin pengering dapat mempengaruhi ketepatan waktu penyediaan linen di ruang rawat inap.

Standar prosedur operasional (SPO) mengenai standar waktu pelayanan linen belum tersedia dan SPO yang terakhir adalah mengenai pengelolaan linen kotor infeksius dan non infeksius per tahun 2006. Kondisi ini merupakan akar masalah lain yang bisa menurunkan mutu pelayanan laundry dan linen RSI Unisma Malang. Tempat setrika yang sempit dan penggunaan setrika biasa menyebabkan hasil setrika tidak rapi dan licin. Pelayanan linen yang kurang memuaskan seperti linen yang tidak memenuhi standar kebersihan, namun tetap digunakan akan mempengaruhi mutu pelayanan RS dan kepuasan pasien.

Tabel 1. Tabel penyebab ketidaktepatan waktu penyediaan linen

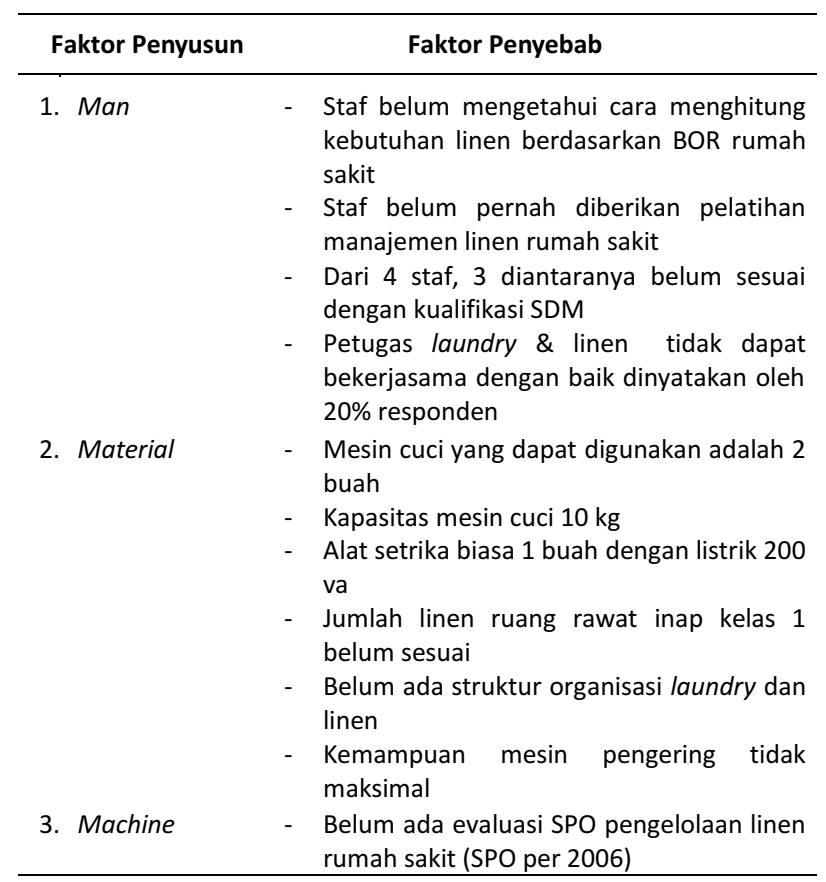

Tabel 1. Tabel penyebab ketidaktepatan waktu penyediaan linen (Lanjutan)

\begin{tabular}{|c|c|}
\hline Faktor Penyusun & Faktor Penyebab \\
\hline 4. Management & 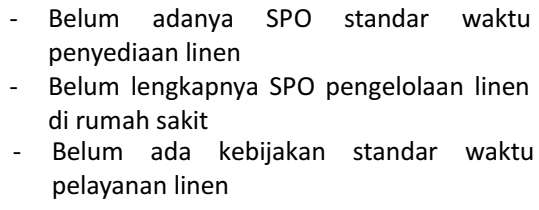 \\
\hline 5. Environment & $\begin{array}{l}\text { - Tempat laundry bersebelahan dengan } \\
\text { incinerator } \\
\text { - Ruang setrika sempit }\end{array}$ \\
\hline
\end{tabular}

\section{Focus Grup Discussion (FGD)}

Identifikasi dari fishbone tersebut dilanjutkan dengan FGD untuk membahas mengenai alternatif solusi ketidaktepatan waktu penyediaan linen. FGD dilaksanakan pada tanggal 21 Oktober 2014 dihadiri Manajer Umum, Kepala Rumah Tangga, IPCN (Infection Prevention and Control Nurse), petugas laundry dan linen. Alternatif solusi ketidaktepatan waktu penyediaan linen ditunjukkan pada Tabel 2.

Alternatif solusi yang dipilih diurutkan dari tingkat produk hingga kesistem manajemen. Langkah awal yang dilakukan oleh pegawai laundry dan linen pada tingkat produk adalah merencanakan pembentukan struktur organisasi instalasi laundry dan linen. Kemudian akan diteruskan pada tingkat proses untuk dilakukan evaluasi SPO pengelolaan linen yang telah ada. SPO pengelolaan linen di RSI Unisma Malang saat ini belum pernah di evaluasi sebelumnya dan SPO ini sudah digunakan sejak tahun 2006. Sesuai dengan kebijakan rumah sakit, SPO wajib di evaluasi setiap 2-5 tahun sekali. Tingkat perencanaan, salah satunya adalah dilakukan penjadwalan inhouse pelatihan manajemen linen kepada staf.

Tabel 2. Identifikasi alternatif solusi

\begin{tabular}{|c|c|c|}
\hline $\begin{array}{c}\text { Tingkat Akar } \\
\text { Masalah }\end{array}$ & Faktor Penyebab & Alternatif Solusi \\
\hline Tingkat Produk & $\begin{array}{l}\text { Rencana pengembangan } \\
\text { manajemen linen rumah } \\
\text { sakit }\end{array}$ & $\begin{array}{l}\text { Merencanakan struktur } \\
\text { organisasi instalasi } \\
\text { laundry dan linen }\end{array}$ \\
\hline Tingkat Proses & $\begin{array}{l}\text { Belum dilakukanevaluasi } \\
\text { SPO pengelolaan linen } \\
\text { rumah sakit }\end{array}$ & $\begin{array}{l}\text { Melakukan evaluasi SPO } \\
\text { pengelolaan linen }\end{array}$ \\
\hline \multirow[t]{4}{*}{$\begin{array}{l}\text { Tingkat } \\
\text { Perencanaan }\end{array}$} & $\begin{array}{l}\text { Belumada SPO standar } \\
\text { waktu pelayanan linen }\end{array}$ & $\begin{array}{l}\text { Membuat SPO standar } \\
\text { waktu pelayanan linen }\end{array}$ \\
\hline & $\begin{array}{l}\text { Belum ada struktur } \\
\text { organisasi instalasi laundry } \\
\text { dan linen } \\
\text { Belum ada pelatihan } \\
\text { manajemen linen kepada } \\
\text { staf laundry dan linen. }\end{array}$ & $\begin{array}{l}\text { Merencanakan struktur } \\
\text { organisasi instalasi } \\
\text { laundry dan linen } \\
\text { Menjadwalkan pelatihan } \\
\text { manajemen linen kepada } \\
\text { staf laundry dan linen. }\end{array}$ \\
\hline & $\begin{array}{l}\text { Instalasi laundry dan linen } \\
\text { belum memahami } \\
\text { manajemen linen } \\
\text { Petugas laundry dan linen } \\
\text { belum memenuhi } \\
\text { kualifikasi }\end{array}$ & $\begin{array}{l}\text { Melakukan in house } \\
\text { training tentang } \\
\text { manajemen linen } \\
\text { Memenuhi kualifikasi } \\
\text { petugas laundry dan linen }\end{array}$ \\
\hline & $\begin{array}{l}\text { Belum mengetahui cara } \\
\text { menghitung kebutuhan } \\
\text { linen berdasarkan BOR }\end{array}$ & $\begin{array}{l}\text { Melakukan in house } \\
\text { training tentang } \\
\text { manajemen linen }\end{array}$ \\
\hline
\end{tabular}


Tabel 2. Identifikasi alternatif solusi (Lanjutan)

\begin{tabular}{lll}
\hline $\begin{array}{c}\text { Tingkat Akar } \\
\text { Masalah }\end{array}$ & \multicolumn{1}{c}{ Faktor Penyebab } & \multicolumn{1}{c}{ Alternatif Solusi } \\
\hline & $\begin{array}{l}\text { rumah sakit } \\
\text { Kemampuan mesin } \\
\text { pengering tidak maksimal, } \\
\text { setrika biasa berjumlah 1 } \\
\text { buah }\end{array}$ & $\begin{array}{l}\text { Mengganti mesin cuci } \\
\text { sekaligus pengering dan } \\
\text { setrika khusus laundry } \\
\text { rumah sakit }\end{array}$ \\
Sistem & waktu pelayanan linen & $\begin{array}{l}\text { Menetapkan kebijakan } \\
\text { standar waktu pelayanan } \\
\text { manajemen }\end{array}$ \\
& & linen \\
\hline
\end{tabular}

\section{Metode dan Skoring AlternatifSolusi}

Pemilihan alternatif solusi dilakukan dengan teori tapisan Mc Namara, dengan menentukan 3 kriteria yang dinilai dari setiap alternatif yaitu kontribusi, kemurahan, dan kelayakan. Tiap kriteria diberikan skor nilai antara 1-5. Total skor tertinggi adalah solusi permasalahan yang dipilih (6). Pemberian skoring dilakukan bersama dengan Manajer Umum, Kepala Rumah Tangga, IPCN (Infection Prevention and Control Nurse), petugas laundry dan linen RSI Unisma Malang. Skoring alternatif solusi pemecahan ketidaktepatan waktu penyediaan linen menggunakan tapisan Mc. Namara ditunjukkan pada Tabel 3.

Langkah awal yang disetujui oleh anggota rapat untuk memperbaiki manajemen laundry dan linen di RSI Unisma Malang adalah penetapan kebijakan standar waktu pelayanan linen. Setelah terbentuk kebijakan langkah berikutnya dilakukan pembentukan struktur organisasi instalasi laundry dan linen, kemudian diikuti oleh pembuatan SPO standar waktu pelayanan linen.

Tabel 3. Metode dan skoring alternatif solusi tapisan Mc. Namara

\begin{tabular}{|c|c|c|c|c|c|c|}
\hline No & Alternatif Solusi & Efektifitas & $\begin{array}{l}\text { Efisiensi } \\
\text { (biaya) }\end{array}$ & Kemudahan & Total & Ket. \\
\hline 1 & $\begin{array}{l}\text { Merencanakan struktur } \\
\text { organisasi instalasi laundry } \\
\text { dan linen }\end{array}$ & $y$ & 4 & 4 & 12 & 2 \\
\hline 2 & $\begin{array}{l}\text { Memenuhi kualifikasi } \\
\text { petugas laundry dan linen }\end{array}$ & 3 & 2 & 2 & 7 & 6 \\
\hline 3 & $\begin{array}{l}\text { Menetapkan kebijakan } \\
\text { standar waktu pelayanan } \\
\text { linen }\end{array}$ & 5 & 4 & 4 & 13 & 1 \\
\hline 4 & $\begin{array}{l}\text { Membuat SPO standar } \\
\text { waktu pelayanan linen }\end{array}$ & 4 & 3 & 3 & 10 & 3 \\
\hline 5 & $\begin{array}{l}\text { Menjadwalkan pelatihan } \\
\text { manajemen linen kepada } \\
\text { staf laundry dan linen. }\end{array}$ & 4 & 2 & 2 & 8 & 5 \\
\hline 6 & $\begin{array}{l}\text { Melakukan in house } \\
\text { training tentang } \\
\text { manajemen linen }\end{array}$ & 3 & 3 & 3 & 9 & 4 \\
\hline 7 & $\begin{array}{l}\text { Mengganti mesin cuci } \\
\text { sekaligus pengering dan } \\
\text { setrika khusus laundry } \\
\text { rumah sakit }\end{array}$ & 3 & 1 & 2 & 6 & 7 \\
\hline
\end{tabular}

\section{DISKUSI}

Faktor-faktor penyebab ketidaktepatan waktu pelayanan linen di RSI Unisma adalah belum ada kebijakan, struktur organisasi, SPO pelayanan linen, dan pelatihan manajemen linen kepada staf laundry dan linen, petugas laundry belum memenuhi kualifikasi, dan kondisi mesin pengering yang tidak maksimal. Masalah tersebut dapat ditangani dengan melakukan pengelolaan manajemen linen. Untuk mengelola menajemen linen yang baik dibutuhkan reformasi di dalam manajemen linen RSI Unisma Malang.

Alternatif solusi yang dapat dilakukan adalah membuat program peningkatan kinerja instalasi laundry dan linen yang dilakukan dengan cara sebagai berikut: 1) memberikan paparan tentang pentingnya instalasi laundry dan linen dan dibentuknya Central Sterile Supply Department (CSSD), 2) membuat struktur organisasi instalasi laundry dan linen beserta tupoksinya, 3) membuat kualifikasi SDM instalasi laundry dan linen, 4) membuat kualifikasi sarana fisik, prasarana, dan peralatan laundry, 5) menetapkan kebijakan standar waktu pelayanan linen, 6) membuat SPO standar waktu pelayanan linen, 7) melakukan sosialisasi SPO standar waktu pelayanan linen, 8) melaksanakan SPO standar waktu pelayanan linen, 9) melakukan evaluasi SPO standar waktu pelayanan linen.

Belum adanya kebijakan mengenai standar waktu pelayanan linen berdampak pada ketidakseimbangan pesan dari pimpinan kepetugas linen tentang pentingnya pengelolaan linen (7). Kebijakan merupakan pedoman untuk menentukan dan melaksanakan program dan kegiatan pelayanan linen. Struktur organisasi laundry dan linen dibutuhkan dalam menterjemahkan kebijakan yang akan dibuat karena berfungsi untuk memudahkan organisasi dalam mengendalikan perilaku para pegawai. Di samping itu, struktur organisasi juga mempengaruhi perilaku dan fungsi kegiatan di dalam organisasi. Dengan demikian, untuk dapat menciptakan efektivitas dan efisiensi organisasi, diperlukan struktur organisasi (7).

Faktor-faktor penyebab ketidaktepatan waktu penyediaan linen untuk ruang rawat inap di RSI Malang Unisma adalah belum ada SPO standar waktu pelayanan linen dan struktur organisasi instalasi laundry dan linen. Kondisi ini mempengaruhi mutu pelayanan linen. Belum adanya SPO standar waktu pelayanan linen membuat petugas tidak mempunyai standar untuk melakukan tindakan pelayanan laundry dan linen (7). Tidak adanya struktur organisasi, membuat petugas bekerja tanpa mengetahui tugas dan fungsi pokok masing-masing (7). Hal ini salah satunya disebabkan karena belum ada kebijakan yang mengatur standar waktu pelayanan linen.

Kualifikasi pendidikan petugas dan adanya SPO tentang pelayanan linen merupakan salah satu kunci keberhasilan dari pengelolaan linen yang baik (8). Untuk meningkatkan pelayanan linen padarawat inap memerlukan pembinaan dan peningkatan pengetahuan petugas laundry dan linen tentang pengelolaan linen. Penelitian yang dilakukan oleh Huda pada tahun 2008 menyebutkan bahwa pelaksaan pengelolaan linen sesuai SPO diperlukan untuk meningkatkan efektivitas pelayanan linen di rawat inap sehingga diperlukan pembuatan SPO standar waktu pelayanan linen yang ditunjang dengan pembuatan SPO pelayanan laundry dan linen yang lainnya. Jika pengelolaan linen dilakukan sesuai SPO diharapkan dapat menghasilkan penurunan kontaminasi dari linen bersih dan risiko infeksi bagi staf akibat laundry dan linen yang kotor (4). Petugas dan perawat rawat inap didorong untuk berpartisipasi dalam implementasi SPO. Selain berfungsi untuk meningkatkan ketepatan waktu penyediaan linen, 
implementasi SPO juga berfungsi untuk program pencegahan dan pengendalian infeksi di rumah sakit.

Rumah sakit mempunyai program pelayanan laundry dan linen, maka rumah sakit harus mendidik dan memberi pelatihan anggota staf tentang program saat mereka mulai bekerja di rumah sakit dan secara berkala serta berkelanjutan. Program pendidikan dan pelatihan ini termasuk untuk petugas laundry, petugas linen ruangan, dan perawat ruang rawat inap (7). Penelitian yang dilakukan oleh Suartama menjelaskan bahwa salah satu faktor yang mempengaruhi kinerja dari petugas adalah pemberian pendidikan dan pelatihan. Pendidikan dan pelatihan memberikan efek positif kepada kemampuan petugas sehingga meningkatkan kinerja dari petugas (9).

\section{DAFTAR PUSTAKA}

1. Departemen Kesehatan Republik Indonesia. Pedoman Manajemen Linen Rumah Sakit. Jakarta: Direktorat Jenderal Pelayanan Medik; 2004.

2. Landers-Mills K. Linen Service Considerations. (Online) 2007. http://c.ymcdn.com/sites/ www.almnet.org/resource/resmgr/Articles _with_contact_hours/Article\%2054\%20-\% 20Linen\% 20Service\%20 Considerations. pdf

3. Sofari B. Manajemen Linen Rumah Sakit. (Online) 2009. http://core.ac.uk/download/pdf/11707162. pdf.

4. Singh D, Qadri GJ, Kotwal M, Syed A, and Jan F. Quality Control in Linen and Laundry Service at a Tertiary Care Teaching Hospital in India. International Journal of Health Sciences. 2009; 3(1): 33-41.

5. Kaur K, Vati J, and Kaur S. Demand and Supply of Bed Linen in Selected Ward of Nehru Hospital. Nursing and Midwifery Researh Journal. 2005; 1(3): 159-165.

6. Sianipar JPG dan Entang HM. Macam-Macam Cara Analisis Manajemen. In: Sianipar JPG dan Entang HM, editors. Teknik-Teknik Analisis Manajemen. Jakarta:
Ruang pencucian dan pengeringan linen memuat mesin cuci dan mesin pengering dengan alur yang jelas antara pemisahan sirkulasi masuk linen kotor dan keluar linen bersih (10). Pada RS Unisma, pintu distribusi linen bersih melewati ruang insinerator, padahal pemisahan sirkulasi masuk linen kotor dan keluar linen bersih diperlukan untuk menghindari kontaminasi (10). Australian Government National Health and Medical Research Council menegaskan bahwa seharusnya ada pemisahan yang jelas bagi tempat linen kotor dan bersih, serta antara yang steril dan tidak steril (11). Tempat laundry RSI Unisma bersebelahan dengan incenerator dapat berdampak pada peningkatan jumlah bakteri pada ruang laundry dan terutama pada linen yang bersih (4) sehingga diperlukan pembenahan letak ruang laundry dan linen RSI Unisma.

Lembaga Administrasi Negara Republik Indonesia; 2001: hal. 22-49.

7. East Cheshire NHS Trust. Guidelines for the Management of Linen \& Laundry. (Online) December 2010. http://www.eastcheshire.nhs.uk/About-TheTrust/policies/L/Linen\%20and\%20Laundry\%20Mana gement\%20ECT1392.pdf

8. Huda N. Analisis Hasil Pengelolaan Linen Rawat Inap di Unit Laundry RSUD Koja Jakarta. [Tesis]. Universitas Indonesia, Jakarta. 2008.

9. Suartama MM dan Ardana K. Analisis Faktor-faktor yang Menentukan Kinerja Karyawan di PT. Arta Boga Cemerlang Denpasar. Manajemen. 2014; 3(5): 12571271.

10. Griffith P, Renz A, Hughes J, and Rafferty AM. The Impact of Organization and Management Factors on Infection Control in Hospitals: A Scoping Review. Journal of Hospital Infection. 2009; 73(1): 1-14.

11. National Health and Medical Research Council. Australian Guidelines for the Prevention and Control of Infection in Healthcare. Canberra: Commonwealth Copyright Administration; 2010 